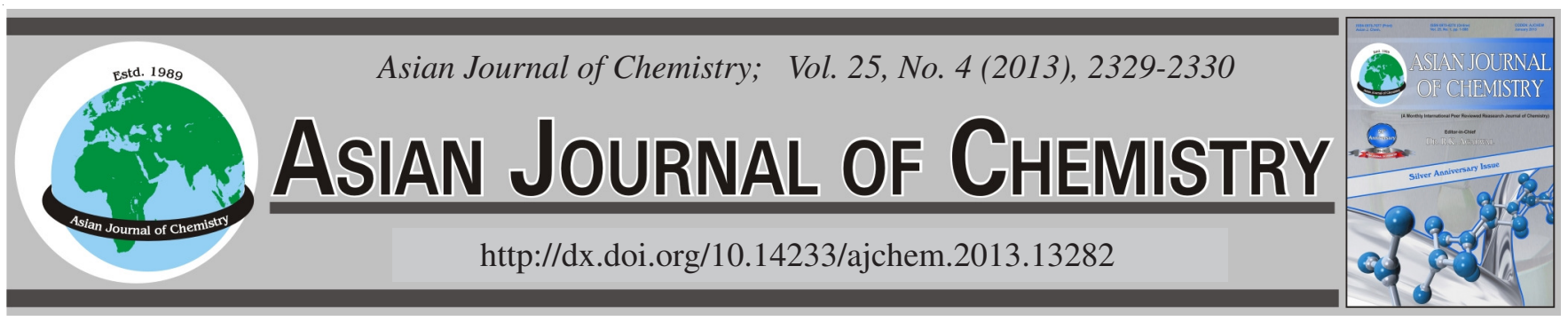

NOTE

\title{
Chemical Composition of Essential Oil of Bauhinia acuminata Leaves
}

\author{
Vipinlal Vasudevan ${ }^{1}$, Joseph Mathew ${ }^{1, *}$ and Sabulal Baby ${ }^{2}$
}

${ }^{1}$ Department of Chemistry, Mar Ivanios College, Thiruvananthapuram-695 015, India

${ }^{2}$ Phytochemistry and Phytopharmacology Division, Tropical Botanic Garden and Research Institute, Pacha-Palode, Thiruvananthapuram695 562, India

*Corresponding author: E-mail: jmathewdr@gmail.com

(Received: 19 December 2011;

Accepted: 26 October 2012)

AJC-12345

\begin{abstract}
Essential oil isolated by hydrodistillation of the fresh leaves of Bauhinia acuminata was analyzed by GC-MS. Nineteen compounds comprising $89.9 \%$ of the leaf oil were identified. The leaf oil was characterized by absence of monoterpenioids. Phytol (65.90 \%) was identified as major constituent in B. acuminata leaf oil. Sesquiterpenoids, $\beta$-caroyphyllene $(13.87 \%)$ and caryophyllene oxide (3.15\%), were the other major constituents.
\end{abstract}

Key Words: Bauhinia acuminata, Essential oil, GC-MS, Phytol, $\beta$-Caryophyllene.

Genus Bauhinia belonging to the family Caesalpiniaceae consists of over 250 species of trees and shrubs ${ }^{1}$. They are distributed in various geographic locations in tropical climates. Plants in genus Bauhinia have characteristic butterfly shaped leaves. Most Bauhinia spp. have applications in traditional medicines. Bauhinia microstachya is used for diabetics in herbal medicine. B. reticulate and B. refescens are used for treatment round worm, conjunctivitis, anthrax, dysentery, blood-poisoning, leprosy and lung disease $\mathrm{s}^{2,3}$. B. variegata is used for skin diseases and ulcerations in Africa. B. variegata bark extracts are used for treatment of cancer in India ${ }^{4}$. Bauhinia acuminata is an ornamental tree with white flowers bearing tropical shade and it is distributed throughout India in warm climates. Previous studies showed juvenomimetic activity of B. acuminata against Dysdercus cingulatus ${ }^{5}$. Its bark is used for the treatment of leucorrhoea and shyphilis ${ }^{6}$. Further, B. acuminata crude extract showed hemolytic activity against human erythrocytes in a dose-dependent manner ${ }^{7}$. GC-MS analysis of the essential oil obtained from $B$. acuminata leaves is reported in the present study.

Fresh leaves of B. acuminata were collected from Thiruvananthapuram, Kerala and the specimen was identified by Dr. Mathew Dan, Tropical Botanic Garden and Research Institute, Pacha-Palode, Thiruvananthapuram.

Extraction of essential oil: Fresh leaves (650 g) were subjected to hydrodistillation for $6 \mathrm{~h}$ using a Clevenger-type apparatus. Pungent smelling, light greenish yellow coloured essential oil $(0.05 \mathrm{~mL}, 0.008 \%$, v/w) was obtained. The oil was dried over anhydrous sodium sulphate and kept at $4{ }^{\circ} \mathrm{C}$ until analyzed.

GC-MS analysis: The essential oil of Bauhinia acuminata leaves was subjected to GC-MS analysis by splitless injection of $1.0 \mu \mathrm{L}$ of the oil on a Hewlett Packard 6890 gas chromatograph fitted with a cross-linked $5 \%$ PH ME siloxane HP-5 MS capillary column $(30 \mathrm{~m} \times 0.32 \mathrm{~mm}, 0.25 \mathrm{~m}$ coating thickness) coupled with a model 5973 mass detector. GC-MS operation conditions: injector temperature $220^{\circ} \mathrm{C}$; transfer line $240{ }^{\circ} \mathrm{C}$; oven temperature programme $60-246^{\circ} \mathrm{C}\left(3^{\circ} \mathrm{C} / \mathrm{min}\right)$; carrier gas helium, $1.4 \mathrm{~mL} / \mathrm{min}$; detector temperature $250^{\circ} \mathrm{C}$. Mass spectra: Electron impact $\left(\mathrm{EI}^{+}\right)$mode $70 \mathrm{eV}$ with a mass range of $40-450 \mathrm{~m} / \mathrm{z}$, ion source temperature $250{ }^{\circ} \mathrm{C}$. Linear retention indices (LRI) of constituents were determined using $n$-alkanes as standards ${ }^{8}$. Individual components were identified by Wiley 275.L database matching, comparison of retention times and comparison of mass spectra of constituents with published data (Table-1).

GC-MS analysis resulted in identification of 19 compounds comprising $89.9 \%$ of B. acuminata leaf oil. Phytol (65.90\%) was the major constituent in the leaf oil. Phytol $(3,7,11,15$ tetramethyl-2-hexadecen-1-ol) is a diterpene alcohol. It is used as a precursor for the manufacture of vitamins $\mathrm{E}$ and $\mathrm{K} 1^{9,10}$. Phytol in esterified form is commonly found in green vegetables as the side chain of chlorophyll molecule. Phytanic acid (3,7,11,15-tetramethyl hexadecanoic acid) is an acid derivative of phytol and human obtain it through the consumption of dietary sources. Free phytol, when administered orally, is 


\begin{tabular}{clcc}
\hline \multicolumn{4}{c}{ TABLE-1 } \\
\multicolumn{4}{c}{$\begin{array}{c}\text { CHEMICAL COMPOSITION OF THE } \\
\text { LEAF OIL OF Bauhinia acuminata }\end{array}$} \\
\hline RT & \multicolumn{1}{c}{ Compound } & LRI $_{\text {cal }}$ & $\%$ \\
\hline 21.54 & $\beta$-Caryophyllene & 1422 & 13.87 \\
22.64 & $\alpha$-Humulene & 1449 & 1.76 \\
22.89 & Isomethyl- $\alpha$-ionone & 1455 & 0.17 \\
23.94 & $\beta$-Ionone & 1482 & 0.10 \\
24.87 & $\alpha$-Farnesene & 1506 & 0.10 \\
27.13 & 1,6,10-Dodecatrien-3-ol & 1566 & 0.26 \\
27.32 & 3-Hexen-1-ol & 1571 & 0.24 \\
27.68 & Caryophyllene oxide & 1580 & 3.15 \\
28.53 & Humulene epoxide (II) & 1502 & 0.35 \\
29.40 & Caryophylla-4(12),8(13)-dien-5 $\alpha$-ol & 1626 & 0.22 \\
29.61 & Caryophylla-4(12),8(13)-dien-5 3 -ol & 1631 & 1.00 \\
29.77 & $\alpha$-Muurolol & 1636 & 0.32 \\
30.25 & $\alpha$-Cadinol & 1648 & 0.40 \\
30.35 & Isoaromadendrene epoxide & 1651 & 0.11 \\
32.80 & Farnesol & 1717 & 0.24 \\
35.24 & 1-Octadecene & 1788 & 0.26 \\
46.33 & Phytol & 2143 & 65.90 \\
46.93 & Sclareolide & 2163 & 0.24 \\
55.91 & Octacosane & 2496 & 0.21 \\
\hline & & &
\end{tabular}

readily absorbed and converted to phytanic acid in rats and humans ${ }^{11}$. Sumac flea beetle Blepharida rhois was reported to use phytol synthesized by its host plant as a deterrent against predation $^{12}$.

Sesquiterpenes and their oxygenated derivatives constituted the second major class of compounds in B. acuminata leaf oil. $\beta$-Caryophyllene (13.87\%), caryophyllene oxide (3.15 $\%)$ and $\alpha$-caryophyllene $(1.76 \%)$ were the major sesquiterpene components. $\beta$-Caryophyllene is a natural bicyclic sesquiterpene with a rare cyclobutene ring. It is usually found in nature as a mixture with $\alpha$-humulene ( $\alpha$-caryophyllene) and isocaryophyllene. It is used in spice blends, citrus flavors, soaps, detergents, creams and lotions and also in a variety of food products and beverages ${ }^{13,14}$. $\beta$-Caryophyllene is known for its antiinflammatory and local anesthetic activities ${ }^{15,16}$. $\beta$ Caryophyllene is also responsible for the spiciness of black pepper $^{17}$.

Previous studies identified the major constituents in volatile oils of Bauhinia species as, $\beta$-elemene $(56.9 \%)$, lepidozenol (22.3\%), $\beta$-bourbonene (12.4\%) (B. aculeata); spathulenol (15.9\%), $\gamma$-elemene $(11.8 \%)$ (B. brevipes); $\alpha$-copaene (28.8\%), $\beta$-caryophyllene $(18.5 \%)$, bicyclogermacrene (14.0\%), $\alpha$-humulene (11.8\%) (B. foficata); spathulenol (27.0\%), $\beta$-caryophylene $(17.4 \%)$, bicyclogermacrene $(12.3 \%)$, isospathulenol (10.8\%) (B. longifolia); $\beta$-caryophyllene (46.6\%), $\alpha$-elemene $(22.6 \%)$, spathulenol (14.1\%) (B. rufa) and germacrene D (24.7\%), -elemene $(18.7 \%)$, spathulenol $(13.3 \%)(\text { B. variegata })^{18}$. Essential oil of $B$. acuminata with phytol and caryophyllenes as its major constituents has a unique chemical profile compared to previously reported Bauhinia species.

\section{ACKNOWLEDGEMENTS}

The authors thank the Head of the Department, Department of Chemistry and The Principal, Mar Ivanios College Thiruvananthapuram for providing laboratory facilities. The authors also acknowledged to Textile Committee, Kannur for GC-MS analysis.

\section{REFERENCES}

1. A. Cronquist, An Integrated System of Classification of Flowering Plants, Columbia University Press: New York, p. 597 (1981).

2. J.M. Watt and M.G. Bryer-Bradwick, The Medicinal and Poisonous Plants of Southern and Eastern Africa, E. \& S. Livingstone: Edinburgh, p. 560 (1962).

3. H.D. Newinger, African Traditional Medicine: A Dictionary of Plant Use and Applications; Medpharm Scientific Publishers: Stuttgart, Germany (2000).

4. J.L. Hartwell, Plants Used Against Cancer, Quaterman Publications: Lawrence, MA, p. 100 (1982).

5. B. Gopalkumar, B. Ambika and V.K.K. Prabhu, Entomon., 2, 259 (1977).

6. K. Mohan and A.K. Singh, Adv. Plant Sci., 9, 1 (1996).

7. K. Phansri, R. Sarnthima, S. Thammasirirak, P. Boonchalee and S. Khammuang, Chiang Mai J. Sci., 38, 242 (2011).

8. R.P. Adams, Identification of Essential Oil Components by Gas Chromatography/Mass Spectroscopy, Allured Publications: Carol Stream, Illinois, USA, edn 4 (2007).

9. T. Netscher, Vitamins Hormones, 76, 155 (2007).

10. M. Alison, J. Richard, E. Mark and D. Andrew, Curr. Org. Chem., 7, 1625 (2003).

11. H. James, J. Lip. Res., 9, 636 (1968).

12. F.V. Venci and T.C. Morton, Chemoecology, 8, 25 (1998),

13. S. Budavari, The Merck Index: An Encyclopedia of Chemicals, Drugs, and Biologicals, Merck \& Co Inc., New Jersey, edn. 12, p. 308 (1996).

14. M. Skold, A.T. Karlberg, M. Matura and A. Borje, Food Chem. Toxicol., 44, 538 (2006).

15. Y. Tambe, H. Tsujiuchi, G. Honda, Y. Ikeshiro and S. Tanaka, Planta Med., 62, 469 (1996)

16. C. Ghelardini, N. Galeotti, Di Cesare and G. Bartolini, Farmaco, 56, 387 (2001).

17. G. Singh, P. Marimuthu, C. Catalan and M.P. deLampasona, J. Sci. Food Agric., 84, 1878 (2004).

18. J.M. Duarte-Almeida, G. Negri and A. Salatino. Biochem. Syst. Ecol., 32, 747 (2004). 